land and by increasing the yields from land already under cultivation.

The programmes of the Colombo Plan countries can now be considered as having genorally passed out of the stage of preparation into that of execution ; but broadly they are only just reaching the stage when tangible returns on any considerable scale can reasonably be expected. Most countries have devoted a large proportion of their programmes to measures which will directly or indirectly increase agricultural output. Improved means of communication and increased sources of power are also basic forms of investment and are essential whatever changes may be made from time to time in the general structure of the economy. The report also stresses the importance of developing human resources; but although not all the programmes include expenditure on such social welfare projects as health, education and housing, which would generally be regarded as adequate, the report recognizes that each country must decide for itself to what extent the growth of social capital should be promoted immediately at the cost of withdrawing capital from more-productive fields.

The successful execution of the individual development plans depends on the extent to which the main components required-capital goods, trained men and finance - are or can be made available, and each country needs continuously to review its develop. ment programme in the light of such available or anticipated resources. Although prices are still high in relation to 1950 levels, the supply of capital goods, provided that finance is available, is not expected to present undue difficulties. As regards trained manpower, the report notes a closer relationship between capital development and technical co-operation, as well as a tendency towards a better balance between training at home and training abroad. The shortterm emphasis on the preparation and execution of plans which will result in increased production in the shortest possible time has encouraged in some countries much reliance on experience and techniques which are at present only available from abroad, whereas longer-term interests demand the development of training facilities in the countries of the region to provide the millions of medium-and lowergrade technicians who will be required in every branch of industry and administration and who can only be trained in their own countries.

Technical co-operation funds have in consequence been used for establishing and equipping training institutions ; although it takes time to develop institutions of this character, unless a start is made now some of the projects already launched may wither away for lack of a supply of trained technicians to operate and expand them. The Technical Co-operation Scheme may have a special part to play also in the provision of equipment for such training institutions. Moreover, the basic concept of the Colombo Plan has been co-operation, with each country doing what it can to assist in the development of the area as a whole. Development schemes in operation in any particular country of the region are likely to be repeated elsewhere with certain modifications, and planners, managers, engineers and trainees can often learn more from such a project in the area than from a completed project in a developed country where conditions may differ widely from those in the region. To promote this kind of training, the Council for Technical Co-operation has agreed that capital expenditure on buildings is a proper charge on a country's contribution to the scheme, provided that substantial benefits are offered to other countries in the area.

The third factor-finance-presents the greatest difficulty ; the countries of the region no longer enjoy the very favourable terms of trade which prevailed for most of them in 1950-51. The prices of most of the exports in 1952-53 had fallen considerably, the terms of trade appreciably worsened and public revenues decreased, while budget deficits replaced, or threatened to replace, the overall budget surpluses of the boom period. Under these conditions, the Governments concerned maintained or increased their expenditure on development only by drawing heavily on their reserves, by external aid in the form of loans or grants, or by raising internal loans. Some even engaged in deficit financing, by borrowing from the banking system to meet their current expenditure.

The risk of inflation is inherent in any intensive investment effort; but the report points out that deficit financing seriously aggravates this riskbecause the consequences of inflation are particularly serious in most countries of the area, deficit financing can only be used to a limited extent. The Colombo Plan programmes are, it is concluded, reaching a critical stage, and their success depends on, besides concentration on the essentials and the fullest use of all available resources, sound internal policies designed to check inflation and secure the highest possible level of saving and investment, and the continuance of external financial aid at least at its present level. Although there has been an appreciable increase in domestic private investment in most of the countries, foreign capital is also required, and the report suggests that a hopeful approach is to invite such capital on a specific project basis on mutually agreeable terms. Finally and significantly, the report notes that the dependence of the area on world markets means that the success of plans for future development largely turns on the outcome of international discussions and the reviews of national economic and trade policies currently proceeding.

\section{NEW NATURE RESERVES IN GREAT BRITAIN}

$T$

HE following six areas in England were declared as new nature reserves on March 9 by the Nature Conservancy : the $\mathbf{5 1 4}$ acres of the Woodwalton Fen, Huntingdon; the addition of 10 acres, known as West Wood, to the Monk's Wood Nature Reserve, already declared on July 1, 1953 ; the 1,628 acres of sand-dunes, salt marsh and shingle ridges at Scolt Head, Norfolk, acquired by the National Trust in 1923 , to which a further 197 acres will shortly be added; the 246 acres of shingle spit at Orfordness and the adjacent 264 acres at Havergate Island of the Orfordness-Havergate Nature Reserve on the Suffolk coast, under agreement with the Royal Society for the Protection of Birds ; 140 acres at Old Winchester Hill, 400-670 ft. above sea-level, in Hampshire; and the five acres of the Swanscombe Skull Site Geological Reserve in the disused Barnfield Gravel Pit in North Kent, which includes much unworked gravel available for research.

Woodwalton Fen has very rich fen flora, including an abundance of species which occur but sparingly 
in East Anglian fen areas, such as the fen violet (Viola stagnina Kit.), the heath violet (Viola canina ssp. montana (L.)) and Luzula pallescens (Wahl) Bess, which are found in only one or two other localities in the British Isles. The Fen is equally rich in insect life. The Scolt Head Nature Reserve is one of the classic localities in the British Isles for the study of coastal erosion and sand-and shingle-bank formation and is scarcely less renowned for the variety and richness of its bird and plant life ; it is one of the main terneries on the North Sea coast of Britain and a wintering area for shore larks and other rare birds. Havergate Island has become famous for the postwar establishment of a successful breeding colony of avocets; under protection, the Island has also acquired colonies of Sandwich terns and other interesting species and has become a very valuable feeding and resting station for many types of migrant birds. The agreement provides for the prohibition of shooting so that the Island may also be a sanctuary for wildfowl in the winter, and its invertebrate fauna includes many semi-marine spiders of a species new to science. Apart from the special interest of its bird and invertebrate fauna, the Orford beach shingle is of particular interest in regard to plant colonization.

The Old Winchester Hill Nature Reserve is situated mostly on the Middle Chalk; but its slopes present a great variety of aspects and, besides showing a wide variety of plants, well demonstrate the influence of rabbits on vegetation. Most of the Reserve is rough chalk grassland; but there are patches of well-grown yew and other chalk-loving trees, juniper, hawthorn and of common ling, while a strip of woodland at the bottom of the hill is spreading as ash seedlings invade the grassland.

In Scotland on March 9 the Nature Conservancy officially declared as a new Scottish nature reserve the area known as Tentsmuir Point, Fife. Before it became part of the Kingdom of Fife, Tentsmuir Point is believed to have been part of Southern Pictavia, the capital of which was at Abernethy. Fragments of pottery of the Bronze Age have been found on the Muir, and the pottery remains are both of the prehistoric iron type and the medieval jug type. The earliest settlers were hunters and fishermen who tended to be nomadic and can scarcely have affected its natural biological balance. The destruction of forests, largely to promote sheep-farming, assumed major proportions during the twelfth century, and among its far-reaching effects was to aggravate soil-blow. By about 1780 Tentsmuir was largely tilled, but even then it was the site of extensive lochs or shallow pools which were ultimately drained by ditching. Reclamation of the marshes also disturbed the biological balance, birds such as the bittern and the crane disappearing. Evidence was given to the Royal Commission on Coastal Erosion in 1911 that between $1853-55$ and $1893-95,534$ acres of land were gained from the sea between St. Andrews and the Tay Estuary and 23 acres lost.

The area now declared consists of 92 acres purchased from the Forestry Commission and, besides dunes and intervening slacks reclaimed by natural processes from the sea, the new reserve includes a large extent of foreshore below the present high-water mark. The rapid gaining of ground from the sea affords an excellent site for the study of colonization, first by strand dune plants tolerant of saline conditions, followed by brackish water plants, and finally by the more usual plants of normal light soils. This varied flora includes several rare species and offers great scope for ecological studies, while the insect fauna and bird life are also of unusual interest. The establishment of the reserve fulfils an agreement of the Forestry Commission with the Dundee Naturalists' Society, when the latter relinquished claim to an area of eighty acres within the Tentsmuir Forest which had been set aside as a bird sanctuary. The Forestry Commission-has also agreed not to plant an adjacent elongated dune slack within the Commission boundary and to make this available for study purposes.

\section{THE NATIONAL PHYSICAL LABORATORY, TEDDINGTON REPORT FOR 1952}

HE annual report for 1952 of the National report of the Executive Committee which was presented to the meeting of the general board on May 15 last, together with the more detailed reports, prepared by the respective superintendents, of the work of the various Divisions of the Laboratory.

The Executive Committee states that the main problem during the year under review was how to obtain maximum progress on the more important items of research with an inedequate staff. It is deplored that much effort had to be devoted to work for defence purposes and many short-term investigations undertaken at the cost of the traditional and fundamental tasks of the Laboratory.

Several changes are mentioned, including the transfer of the Radio Division of the Laboratory, first set up in 1933, to the Radio Research Organization and, in view of the close connexion between the work of the High Temperature Mechanical Properties Section and that of the Metallurgy Division in the high-temperature materials field, the incorporation of the Section in the Division until it can be transferred to the Mechanical Engineering Research Laboratory, East Kilbride, probably in five years time. Permission to proceed with the design of the new ship tank and cavitation tunnel to be built at Feltham was obtained, and considerable progress is reported with this work and on the construction of the building for the new High Speed Laboratory on the West Aero site to contain two new high-speed wind tunnels. The room in the aerodynamics building which contained the last remaining 4 -ft. wind tunnel is to be used to house the DEUCE (digital electronic universal computing engine), the engineered version of the pilot model of the ACE (automatic computing engine), and when the new high-speed tunnels come into operation it is intended to convert the large building at present occupied by the duplex tunnel into a much-needed large lecture hall with accommodation for 350 people and into a canteen with adequate facilities for staff and visitors.

The annual open day ${ }^{1}$ was held on May 23, 1952, and was attended by many scientific workers from the universities, government departments and indus. try, and a well-attended conference on the measurement and importance of the elastic properties of metals ${ }^{2}$ took place during March 20-21. On April 22 the Laboratory was honoured by a visit from H.R.H. the Duke of Edinburgh, who spent the morning National Physical Laboratory: Report for the Year 1952. Pp.
viii +72. (London: H.M.S.O., 1953.) 28. 6d. net. 